Tropical Journal of Pharmaceutical Research April 2019; 18 (4): 781-790

ISSN: $1596-5996$ (print); 1596-9827 (electronic)

(C) Pharmacotherapy Group, Faculty of Pharmacy, University of Benin, Benin City, 300001 Nigeria.

\title{
Hepatoprotective, nephroprotective, anti-amylase, and anti- glucosidase effects of Ziziphus spina-christi (L.) against carbon tetrachloride-induced toxicity in rats
}

\author{
Amal Ahmed Mohammed Al-Ghamdi ${ }^{1}$, Manal El-Zohri ${ }^{1,2}$, Abdelaaty A Shahat ${ }^{3,4 *}$ \\ ${ }^{1}$ Department of Botany, Environment Program, Faculty of Biological Science, King Abdulaziz University, PO Box 35009, Jeddah \\ 21488, Saudi Arabia, ${ }^{2}$ Department of Botany and Microbiology, Faculty of Science, Assiut University, Assiut 71516, Egypt, \\ ${ }^{3}$ Pharmacognosy Department, College of Pharmacy, King Saud University, PO Box 2457, Riyadh 11451, Saudi Arabia, \\ ${ }^{4}$ Phytochemistry Department, National Research Centre, 33 El Bohouth St, PO Box 12622, Dokki, Giza, Egypt
}

*For correspondence: Email: aashahat@hotmail.com, ashahat@ksu.edu.sa

\begin{abstract}
Purpose: To explore the hepatoprotective, nephroprotective, anti-amylase, and anti-glucosidase effects of the medicinal plant Ziziphus spina-christi (L.).

Methods: Ziziphus spina-christi (L.) methanol extract (ZS-1) and its ethyl-acetate (ZS-2), n-butanol (ZS$3)$, and aqueous (ZS-4) fractions were evaluated for their hepatoprotective, anti-amylase, and antiglucosidase activities. Adult male Wister rats were divided into 11 groups (I- XI) with 6 mice per group. Group I was normal control, while the treatment groups were as follows: group II, CCl4; group III, Silymarin + $\mathrm{CCl}_{4}$; group IV, Ziziphus spina-christi total methanol extract (ZS-1), $\left.100 \mathrm{mg} / \mathrm{kg}\right)+\mathrm{CCl}_{4}$; group V, ZS-1 (200 mg/kg) + CCl ; group VI, ethyl acetate fraction (ZS-2), $100 \mathrm{mg} / \mathrm{kg}+\mathrm{CCl}_{4}$; group VII: ZS-2 (200 mg/kg) + CCl4; group VIII, butanol fraction (ZS-3), $100 \mathrm{mg} / \mathrm{kg})+\mathrm{CCl}_{4}$; group IX, ZS-3 (200 $\mathrm{mg} / \mathrm{kg})+\mathrm{CCl}_{4} ;$ group $X$, aqueous fraction $\left.(Z S-4), 100 \mathrm{mg} / \mathrm{kg}\right)+\mathrm{CCl}_{4} ;$ group XI: ZS-4 (200 mg/kg) + $\mathrm{CCl}_{4}$. Silymarin was used as the standard. Biomarkers of liver and kidney toxicity and histopathological changes were evaluated.

Results: Liver and kidney malondialdehyde (MDA), non-protein sulfhydryls (NP-SH) and total protein levels were elevated in $\mathrm{CCl}_{4}$-treated rats; however, ZS-1 and ZS-4 of Z. spina-christi significantly reduced these levels. ZS-2 and ZS-3 did not significantly improve the studied parameters. These results were confirmed by results from histopathological examination. ZS-1 and ZS-2 showed mild inhibitory activities against $\alpha$-amylase and $\alpha$-glucosidase (54 and $43 \%$ at $100 \mu \mathrm{g} / \mathrm{ml}$, respectively).

Conclusion: The results indicate that ZS-1 and ZS-4 samples displayed dose-dependent hepatoprotective and nephroprotective effects, whereas ZS-2 and ZS-3 samples did not exhibit these effects. Similarly, $\alpha$-amylase and $\alpha$-glucosidase enzymes are considerably inhibited by ZS-1 and ZS-2.
\end{abstract}

Keywords: Ziziphus spina christi, Rhamnaceae, Hepatoprotective, Nephroprotection, $\alpha$-Amylase and $\alpha$ Glucosidase

This is an Open Access article that uses a fund-ing model which does not charge readers or their institutions for access and distributed under the terms of the Creative Commons Attribution License (http://creativecommons.org/licenses/by/4.0) and the Budapest Open Access Initiative (http://www.budapestopenaccessinitiative.org/read), which permit unrestricted use, distribution, and reproduction in any medium, provided the original work is properly credited.

Tropical Journal of Pharmaceutical Research is indexed by Science Citation Index (SciSearch), Scopus, International Pharmaceutical Abstract, Chemical Abstracts, Embase, Index Copernicus, EBSCO, African Index Medicus, JournalSeek, Journal Citation Reports/Science Edition, Directory of Open Access Journals (DOAJ), African Journal Online, Bioline International, Open-J-Gate and Pharmacy Abstracts

\section{INTRODUCTION}

Many environmental impurities, drugs, chemicals, and antibiotics exert numerous adverse effects on the kidney, liver, intestine, and heart [1]. The liver is a remarkably important organ with the critical function of regulating physiological activities. It is involved in almost all 
biochemical processes in the body such as development, nutrient delivery, disease progression, reproduction, and energy provision. In addition, the liver supports the metabolism of proteins and carbohydrates, fat detoxification, bile secretion, and vitamin storage [2]. The liver is often damaged by one's surrounding environment, toxins, alcohols, and over-thecounter treatments, ultimately leading to hepatitis, cirrhosis, and liver disorders [3]. Therefore, treating liver diseases is very important. Over the centuries, medicinal plants have been used to manage several human diseases and play very significant roles in the health care system globally [4]. Diabetes is an advanced metabolic disease of glucose metabolism, and in the long-term, leads to microvascular variations [5].

In Saudi Arabia, the local name for Zizyphus spina-christi $(\mathrm{L})$ is Sidr. Sidr is a shrub belonging to the Rhamnaceae family and is indigenous to warm and subtropical areas including North Africa, the South and Middle East, East of Asia, Mediterranean region, South Europe, Australia, and tropical America [6]. The edible fruit of $Z$. spina-christi is important in the medical field as it is applied to ulcers and cuts. Essentially, the fruit is used to treat pulmonary diseases and fevers, and for healing fresh wounds [7]. In folk medicine, Sidr is used to heal several ailments such as liver complaints, urinary issues, digestive syndromes, weakness, obesity, diabetes, skin infection, appetite loss, fever, bronchitis, pharyngitis, anemia, insomnia and diarrhea [8]. The Sidr leaves are locally applied to sores while the roots are used to treat skin diseases [9]. The seeds are at times ingested with buttermilk to halt vomiting, treat nausea and abdominal problems related to pregnancy, and for their sedative effects [10]. The leaves are used to treat liver diseases, fever and asthma [11]. Additionally, Ziziphus spina-christi leaves have been reported to exhibit significant antioxidant and hypoglycemic activities [12] and are rich in ceanothic, betulinic acids, saponins, various flavonoids, triterpenes, tannins and flavonoids [13]. The aim of the current study was to evaluate the hepatoprotective, nephroprotective, and anti- $\alpha$-amylase and anti- $\alpha$-glucosidase activities of Ziziphus spina-christi.

\section{EXPERIMENTAL}

\section{Plant material}

Ziziphus spina-christi leaves were collected from Mecca Road, Jeddah, Saudi Arabia in April 2016. The plant was authenticated by Prof Kadry Abdelkhalik (Biology Department, Faculty of
Science, Umm Al-Qura University, Mecca, Kingdom of Saudi Arabia). A voucher specimen (no. (Sh-Am-2016) is stored in the herbarium of the Faculty of Biological Science, King Abdulaziz University, Jeddah, Saudi Arabia.

\section{Extract preparation}

Air-dried, grinded (1.2 kg leaves) Z. spina-christi material was immersed in $80 \%$ methanol for three days, then filtered and evaporated with a rotary evaporator. A greenish residue was obtained as the methanol extract. A portion of this extract (ZS-1) was used for bioscreening purposes while the remaining portion was partitioned using a separating funnel where polarity of the solvent was increased using $n$ hexane, chloroform, ethyl acetate (ZS-2), and $n$ butanol (ZS-3); an aqueous fraction (ZS-4) was also obtained.

\section{Animals and experimental design}

A total of 66 albino male rats weighing $160 \pm 11 \mathrm{~g}$ was retrieved from the Experimental Center of Animal, Faculty of Pharmacy., King Saud University, Riyadh, Kingdom of Saudi Arabia. The rats were supplied with water and food, and housed at $22-25^{\circ} \mathrm{C}$ under a $12-\mathrm{h}$ dark-light cycle. All animals were handled as per the approvals of the 'Guide for the Care and Use of Laboratory Animals' permitted by the Institutional Animal Ethics Committee of the College of Pharmacy, King Saud University, Riyadh, Saudi Arabia (clearance no. CBR-4538) [12]. Prior to the start of the experiments, rats were adapted to the conditions of the laboratory for 7 days. The animals were randomly divided into 11 groups (6 rats each) with the details of each listed in Table 1. Carbon tetrachloride $\left(\mathrm{CCl}_{4}\right)$ in liquid paraffin was administered intraperitoneally (IP) to the rodents.

Table 1: Classification of rat groups

\begin{tabular}{|c|c|c|}
\hline Groups & Treatment & Dose \\
\hline Group I & Normal control & - \\
\hline Group II & $\mathrm{CCl}_{4}$ & $1.25 \mathrm{~mL} / \mathrm{kg}$ \\
\hline Group III & Silymarin $+\mathrm{CCl}_{4}$ & $50 \mathrm{mg} / \mathrm{kg}$ \\
\hline Group IV & $(\mathrm{ZS}-1)+\mathrm{CCl}_{4}$ & $100 \mathrm{mg} / \mathrm{kg}$ \\
\hline Group V & $(Z S-1)+\mathrm{CCl}_{4}$ & $200 \mathrm{mg} / \mathrm{kg}$ \\
\hline Group VI & $(\mathrm{ZS}-2)+\mathrm{CCl}_{4}$ & $100 \mathrm{mg} / \mathrm{kg}$ \\
\hline Group VII & $(\mathrm{ZS}-2)+\mathrm{CCl}_{4}$ & $200 \mathrm{mg} / \mathrm{kg}$ \\
\hline Group VIII & $(\mathrm{ZS}-3)+\mathrm{CCl}_{4}$ & $100 \mathrm{mg} / \mathrm{kg}$ \\
\hline Group IX & $(\mathrm{ZS}-3)+\mathrm{CCl}_{4}$ & $200 \mathrm{mg} / \mathrm{kg}$ \\
\hline Group X & $(\mathrm{ZS}-4)+\mathrm{CCl}_{4}$ & $100 \mathrm{mg} / \mathrm{kg}$ \\
\hline Group XI & $(\mathrm{ZS}-4)+\mathrm{CCl}_{4}$ & $200 \mathrm{mg} / \mathrm{kg}$ \\
\hline
\end{tabular}




\section{Blood and tissue sampling}

At the end of the experimental period, animals from the different groups were starved for $12 \mathrm{~h}$ then weighed. Blood samples were collected from the sublingual vein, left to coagulate at room temperature, and centrifuged for $15 \mathrm{~min}$ at 3000 rpm. The non-hemolyzed, clear serum was quickly separated and stored at $-80^{\circ} \mathrm{C}$ for use in biochemical investigations of lipid profile, and liver and kidney function parameters. Animals were sacrificed using diethyl ether anesthesia, and the liver and kidney tissues were rapidly removed and divided into two parts; one was immediately preserved in 10\% buffered formalin at $4{ }^{\circ} \mathrm{C}$ for histological examination and the remaining part stored at $-80^{\circ} \mathrm{C}$ for biochemical analysis.

\section{Biochemical analysis}

Marker enzymes, including serum glutamate oxaloacetate transaminase (SGOT), alkaline phosphatase (ALP), serum glutamate pyruvate transaminase (SGPT), gamma-glutamyl transferase (GGT), hemoglobin, and bilirubin were analyzed using the kits from Reflotron Plus Analyzer and Roche (Roche Diagnostics $\mathrm{GmbH}$, Mannheim, Germany).

\section{Evaluation of kidney functions}

Reflotron Plus Analyzer and Roche kits (Roche Diagnostics $\mathrm{GmbH}$, Mannheim, Germany) were used to determined creatinine and uric acid levels (in $\mathrm{mg} / \mathrm{dL}$ ).

\section{Assessment of liver functions}

SGOT enzyme, SGPT activities, alkaline phosphatase (ALP) activity and total bilirubin concentration were measured by the methods described by Ullah et al [14].

\section{Determination of malondialdehyde (MDA)}

The method reported by Utley et al was used to determine the level of malondialdehyde (MDA). In brief, the kidney and liver samples were isolated and then immersed in $0.15 \mathrm{M} \mathrm{KCl}$ using an electric homogenizer. Color development was observed at $532 \mathrm{~nm}$ using a UV/Vis spectrophotometer. Malondialdehyde content was calculated using an MDA standard curve.

\section{Total protein determination (TP)}

The total protein was assessed using kit delivered by Crescent Diagnostics, Jeddah, KSA. Protein concentration measured by measuring the developed colour at $546 \mathrm{~nm}$ with the help of UV-Vis-Spetrophotometer Model UV-mini-1240, Shimadzu (Japan).

\section{Non-protein sulfhydryls (NP-SH) assay}

Renal non-protein sulfhydryls were calculated by the method of Sedlak and Lindsay [15]. Kidney samples were grinded in ethylene diamine tetraacetic acid $(0.02 \mathrm{mmol} / \mathrm{L})$ at $4{ }^{\circ} \mathrm{C}$. A $5 \mathrm{~mL}$ aliquot of the homogenized kidney was added to $4 \mathrm{~mL}$ of water and $1 \mathrm{~mL}$ of trichloroacetic acid (TCA) $(50 \%)$, which were blended spasmodically and then centrifuged at $3000 \mathrm{rpm}$ for $10 \mathrm{~min}$. Two $\mathrm{mL}$ of the clear extract was added to $4 \mathrm{~mL}$ of $0.4 \mathrm{mmol} / \mathrm{L}$ Tris buffer $(\mathrm{pH} 8.9)$ and $0.1 \mathrm{~mL}$ of 2-nitrobenzoic acid (5, 5'-dithio-bis) (DTNB) added, with shaking, to the sample. Color development was measured at $412 \mathrm{~nm}$.

\section{Assessment of alpha-amylase and alpha- glucosidase activity}

Inhibition of amylase activity in plant samples was evaluated as described by Sabitha et al [16], while inhibition of glucosidase activity was determined based on the method of Hossan et al [17].

\section{Histopathological investigation}

Specimens from liver tissues were taken and fixed in buffered neutral formalin solution (10\%) for $24 \mathrm{~h}$. Samples were dehydrated via a graded alcohol series, which was removed using xylol before embedding the samples in paraffin. Tissues were cut into $6 \mu \mathrm{m}$-thick sections with a microtome, which were stained with hematoxylin eosin (HE) and photographed using a light microscope.

\section{Statistical analysis}

The collected data are expressed as mean \pm standard error (SE) and were statistically analyzed using the Student's t-test or one-way analysis of variance (ANOVA), followed by Dunnett's multiple comparison test. Significant differences between the treatment groups were found at $p<0.05, p<0.01$ or $p<0.001$.

\section{RESULTS}

As shown in Table 2, SGOT, SGPT, GGT, ALP, and bilirubin levels were significantly increased in $\mathrm{CCl}_{4}$-induced hepatotoxic rats compared to those in the normal controls. Treatment with ZS-1 (100 $\mathrm{mg} / \mathrm{kg})$, ZS-1 (200 mg/kg), ZS-4 (100 mg/kg), and ZS-4 $(200 \mathrm{mg} / \mathrm{kg})$ reduced these elevated levels compared to the levels in the $\mathrm{CCl}_{4}$-only 
group, and high dose (200 mg/kg of body weight) ZS-1 and ZS-4 treatment showed almost similar effects to silymarin treatment $(10 \mathrm{mg} / \mathrm{kg}$ body weight). Administering ZS-2 (100 mg/kg), ZS-2 (200 mg/kg), and ZS-3 (100 mg/kg) did not lead to significant results when compared to those observed in the $\mathrm{CCl}_{4}$ only group (Table 2).

Effect of Z. spina-christi extract/fraction on NP-SH, MDA, and total protein in liver tissue

MDA levels in the liver tissue of $\mathrm{CCl}_{4}$-induced rats were significantly higher $(p>0.001)$ than those in the controls (Table 3).

\section{Effect of Z. spina-christi extract/fractions on kidney functions}

An evident increase in creatinine and uric acid levels was observed in the treated groups compared to that in the control group (Table 4). Therefore, administering different fractions of ZS$1(100,200 \mathrm{mg} / \mathrm{kg})$ and ZS-4 (100, $200 \mathrm{mg} / \mathrm{kg})+$ $\mathrm{CCl}_{4}$ showed a defensive capacity against $\mathrm{CCl}_{4}$ intoxication, as serum creatinine and uric acid levels were restored in rats. However, there were no significant changes in uric acid and serum creatinine levels in the ZS-2 (100, $200 \mathrm{mg} / \mathrm{kg})$ and ZS-3 (100, $200 \mathrm{mg} / \mathrm{kg})$ treated groups.

Table 2: Effect of Zizyphus spina-christi L. extract and its fractions on liver function in rats given $\mathrm{CCl}_{4}$

\begin{tabular}{|c|c|c|c|c|c|}
\hline Group & SGOT (U/L) & SGPT (U/L) & GGT (U/L) & ALP (U/L) & $\begin{array}{c}\text { Bilirubinn } \\
\text { (mg/dL) }\end{array}$ \\
\hline Normal & $75.3 \pm 2.1$ & $25.4 \pm 1.8$ & $4.1 \pm 0.2$ & $344.8 \pm 7.7$ & $0.5 \pm 0.01$ \\
\hline $\mathrm{CCl}_{4}$ & $305.1 \pm 5.5^{\star \star \star}$ & $275.6 \pm 9.4^{\star \star *}$ & $17.9 \pm 0.5^{* * *}$ & $657.8 \pm 16.0^{\star \star *}$ & $2.93 \pm 0.06^{\star * *}$ \\
\hline Silymarin & $132.0 \pm 7.5^{\star \star \star}$ & $97.3 \pm 5.7^{\star \star \star}$ & $6.1 \pm 0.2^{\star \star \star}$ & $426.6 \pm 8.6^{\star * *}$ & $0.9 \pm 0.06^{\star * *}$ \\
\hline$(10 \mathrm{mg} / \mathrm{kg})$ & $57 \%$ & $65 \%$ & $66 \%$ & $35 \%$ & $67 \%$ \\
\hline ZS-1 & $263.1 \pm 5.4^{\star * *}$ & $199.1 \pm 6.1^{\star \star \star}$ & $14.2 \pm 0.5^{\star \star *}$ & $588.6 \pm 8.4^{* *}$ & $2.02 \pm 0.07^{\star \star *}$ \\
\hline$(100$ mg/kg) & $14 \%$ & $28 \%$ & $20 \%$ & $11 \%$ & $31 \%$ \\
\hline ZS-1 & $228.1 \pm 12.9^{* * *}$ & $165.0 \pm 4.3^{* \star *}$ & $10.8 \pm 0.5^{\star * *}$ & $502.8 \pm 7.6^{* * *}$ & $1.68 \pm 0.05^{\star * *}$ \\
\hline$(200$ mg/kg) & $25 \%$ & $40 \%$ & $39 \%$ & $24 \%$ & $44 \%$ \\
\hline ZS-2 & $291.8 \pm 15.5$ & $271.1 \pm 8.0$ & $16.5 \pm 0.4$ & $663.6 \pm 8.2$ & $2.97 \pm 0.06$ \\
\hline$(100$ mg/kg) & $4 \%$ & $-\%$ & $7 \%$ & $-\%$ & $-\%$ \\
\hline ZS-2 & $302.0 \pm 5.6$ & $253.1 \pm 5.4$ & $15.3 \pm 0.2^{* *}$ & $643.1 \pm 8.2$ & $2.91 \pm 0.05$ \\
\hline (200 mg/kg) & $-\%$ & $8 \%$ & $14 \%$ & $-\%$ & $-\%$ \\
\hline ZS-3 & $310.6 \pm 5.2$ & $292.8 \pm 5.5$ & $17.4 \pm 0.2$ & $690.5 \pm 5.5$ & $2.94 \pm 0.06$ \\
\hline$(100 \mathrm{mg} / \mathrm{kg})$ & $-\%$ & 6 & $-\%$ & $-\%$ & $-\%$ \\
\hline ZS-3 & $288.6 \pm 4.5^{\star}$ & $254.3 \pm 5.1$ & $16.3 \pm 0.2^{*}$ & $548.8 \pm 10.5$ & $2.8 \pm 0.04$ \\
\hline$(200$ mg/kg) & $5 \%$ & $8 \%$ & 8 & $-\%$ & $4 \%$ \\
\hline ZS-4 & $275.0 \pm 5.4^{* *}$ & $175.1 \pm 8.0^{* * *}$ & $12.1 \pm 0.5^{\star \star \star}$ & $554.3 \pm 13.8^{\star * *}$ & $1.9 \pm 0.07^{\star * *}$ \\
\hline$(100 \mathrm{mg} / \mathrm{kg})$ & $10 \%$ & $36 \%$ & $32 \%$ & $16 \%$ & $33 \%$ \\
\hline ZS-4 (200 & $207.6 \pm 7.9^{* * *}$ & $143.8 \pm 4.7^{* * *}$ & $7.8 \pm 0.5^{\star \star *}$ & $504.6 \pm 10.6^{* * *}$ & $1.4 \pm 0.03^{\star * *}$ \\
\hline $\mathrm{mg} / \mathrm{kg}$ ) & $32 \%$ & $47 \%$ & $56 \%$ & $23 \%$ & $51 \%$ \\
\hline
\end{tabular}

Each value represents mean \pm SEM $(\mathrm{n}=3),{ }^{\star * *} p<0.001 ;{ }^{* *} p<0.01 ;{ }^{*} p<0.05 ; 1, \mathrm{CCl}_{4}$ group compared to the normal group; 2, Treated groups compared to the $\mathrm{CCl}_{4}$ group

Table 3: Effect of Zizyphus spina-christi L. extract and its fractions on MDA, total protein and NP-SH in liver tissue of rats given $\mathrm{CCl}_{4}$

\begin{tabular}{|c|c|c|c|}
\hline Group & $\begin{array}{c}\text { MDA } \\
(\mathrm{nmol} / \mathrm{g})\end{array}$ & $\begin{array}{l}\text { Total protein } \\
\text { ( } \mu \mathrm{g} / \mathrm{mg} \text { tissue) }\end{array}$ & $\begin{array}{c}\text { NP-SH } \\
(\mathrm{nmol} / \mathrm{g})\end{array}$ \\
\hline Normal & $0.70 \pm 0.032$ & $100.99 \pm 4.60$ & $5.46 \pm 0.20$ \\
\hline $\mathrm{CCl}_{4}$ & $5.73 \pm 0.20^{\star \star \star}$ & $37.92 \pm 1.68^{* * *}$ & $3.41 \pm 0.15^{\star \star *}$ \\
\hline Silymarin (10 mg/kg) & $1.32 \pm 0.04^{* * *}$ & $86.22 \pm 3.09^{* * *}$ & $4.90 \pm 0.25^{\star * *}$ \\
\hline ZS-1 (100 mg/kg) & $3.53 \pm 0.2^{\star \star \star}$ & $54.29 \pm 2.01^{* *}$ & $4.28 \pm 0.32^{*}$ \\
\hline ZS-1 (200 mg/kg) & $1.99 \pm 0.07^{\star * *}$ & $76.24 \pm 3.11^{* * *}$ & $4.54 \pm 0.21^{* *}$ \\
\hline ZS-2 (100 mg/kg) & $4.55 \pm 0.02^{\star *}$ & $45.50 \pm 2.14^{*}$ & $3.45 \pm 0.13$ \\
\hline ZS-2 (200 mg/kg) & $3.31 \pm 0.08^{* * *}$ & $55.08 \pm 1.51^{* * *}$ & $3.64 \pm 0.19$ \\
\hline ZS-3 (100 mg/kg) & $5.26 \pm 0.35$ & $40.31 \pm 1.79$ & $3.61 \pm 0.18$ \\
\hline ZS-3 (200 mg/kg) & $3.66 \pm 0.08^{\star * *}$ & $55.48 \pm 1.43^{* * *}$ & $3.93 \pm 0.23$ \\
\hline ZS-4 (100 mg/kg) & $2.58 \pm 0.07^{\star \star \star}$ & $66.26 \pm 2.01^{\star \star *}$ & $4.75 \pm 018^{\star * *}$ \\
\hline ZS-4 (200 mg/kg) & $1.77 \pm 0.06^{\star * *}$ & $77.04 \pm 2.26^{* * *}$ & $5.08 \pm 0.29^{* * *}$ \\
\hline
\end{tabular}

Each value represents mean \pm SEM $(\mathrm{n}=3),{ }^{* * *} p<0.001 ;{ }^{* *} p<0.01 ;{ }^{*} p<0.05 ; 1, \mathrm{CCl}_{4}$ group compared to the normal group; 2, treated groups compared to the $\mathrm{CCl}_{4}$ group 
Effects of Z. spina-christi extract/fractions on NP-SH, MDA, and total protein in kidney tissue

As shown in Table 5, the levels of MDA, total protein, and NP-SH in kidney samples from animals administered $\mathrm{CCl}_{4}$ were significantly increased compared to those in normal control rats.

Treatment with ZS-1 $(100,200 \mathrm{mg} / \mathrm{kg})$ and ZS-4 $(100,200 \mathrm{mg} / \mathrm{kg})$ caused dose-dependent and significant changes in the levels of these markers compared to the levels found in the $\mathrm{CCl} 4$ only group. Although administering ZS-2 (100, 200 $\mathrm{mg} / \mathrm{kg})$ and ZS-3 $(100 \mathrm{mg} / \mathrm{kg})$ did not result in considerable changes, ZS-2 (200 mg/kg) treatment significantly reduced the concentration of MDA, but this was only relative to the $\mathrm{CCl} 4$ group.

\section{Inhibition of $\alpha$-amylase}

The inhibition of $\alpha$-amylase caused by the plant extract or the different fractions is represented in Figure 1. Among the 4 samples tested, the ZS-1 extract and ZS-2 fraction caused considerable inhibition compared to the other extracts in the following order: ZS-2 > ZS-1 > ZS-3 > ZS-4. ZS2 exhibited the highest inhibition, whereas ZS-4 exhibited the lowest inhibition at a concentration of $100 \mu \mathrm{g} / \mathrm{ml}$. The ZS-2 fraction showed $63 \%$ inhibition at $100 \mu \mathrm{g} / \mathrm{mL}$ followed by ZS-1, $52 \%$; ZS-3, 47\%; and ZS-4, 28\%.

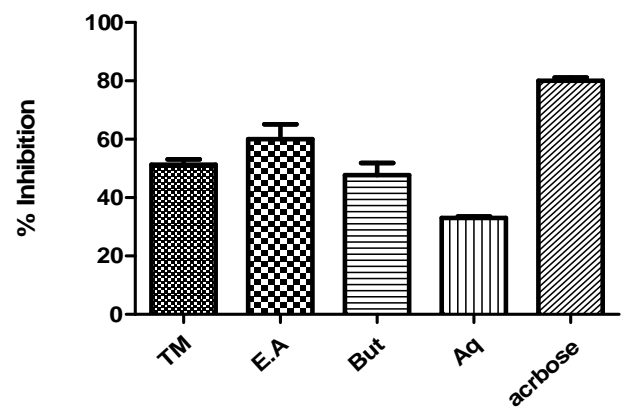

Figure 1: Inhibition of alpha-amylase activity by the plant extract and fractions. ZS-4 (Aq); ZS-3(But); ZS2(EA); ZS-1(TM)

Table 4: Effect of $Z$. spina-christi L. extract and its fractions on kidney functions in $\mathrm{CCl}_{4}$ intoxicated rats

\begin{tabular}{lcc}
\hline Group & Creatinine $(\mathrm{mg} / \mathrm{dL})$ & Uric acid $(\mathrm{mg} / \mathrm{dL})$ \\
\hline Normal & $1.16 \pm 0.06$ & $2.32 \pm 0.17$ \\
CCl $_{4}$ & $4.07 \pm 0.13^{* * *}$ & $8.19 \pm 0.39^{* * *}$ \\
Silymarin $(10 \mathrm{mg} / \mathrm{kg})$ & $1.75 \pm 0.09^{* * *}(57 \%)$ & $3.40 \pm 0.12^{* * *}(58 \%)$ \\
ZS-1 $(100 \mathrm{mg} / \mathrm{kg})$ & $3.77 \pm 0.08(7 \%)$ & $5.58 \pm 0.33^{* * *}(32 \%)$ \\
ZS-1 $(200 \mathrm{mg} / \mathrm{kg})$ & $2.85 \pm 0.18^{* * *}(30 \%)$ & $5.08 \pm 0.26^{* *} 38 \%$ \\
ZS-2 $(100 \mathrm{mg} / \mathrm{kg})$ & $4.35 \pm 0.11(-\%)$ & $8.79 \pm 0.40(-\%)$ \\
ZS-2 $(200 \mathrm{mg} / \mathrm{kg})$ & $4.06 \pm 0.12(-\%)$ & $6.96 \pm 0.22(4 \%)$ \\
ZS-3 $(100 \mathrm{mg} / \mathrm{kg})$ & $4.19 \pm 0.13(-\%)$ & $8.54 \pm 0.38(-\%)$ \\
ZS-3 $(200 \mathrm{mg} / \mathrm{kg})$ & $3.99 \pm 0.10(-\%)$ & $8.04 \pm 0.31(-\%)$ \\
ZS-4 $(100 \mathrm{mg} / \mathrm{kg})$ & $3.26 \pm 0.12^{* *}(20 \%)$ & $4.83 \pm 0.22^{* * *}(41 \%)$ \\
ZS-4 $(200 \mathrm{mg} / \mathrm{kg})$ & $2.50 \pm 0.10^{* * *}(38 \%)$ & $4.04 \pm 0.24^{* * *}(51 \%)$ \\
\hline
\end{tabular}

Each value represents mean \pm SEM $(n=3),{ }^{* * *} p<0.001 ;{ }^{* *} p<0.01 ;{ }^{*} p<0.05 ; 1, C C l_{4}$ group compared to the normal group; 2, Treated groups compared to the $\mathrm{CCl}_{4}$ group.

Table 5: Effect of Zizyphus spina-christi L. extract and its fractions on MDA, total protein and NP-SH in kidney tissue of rats given $\mathrm{CCl}_{4}$

\begin{tabular}{|c|c|c|c|}
\hline Group & $\begin{array}{c}\text { MDA } \\
(\mathrm{nmol} / \mathrm{g})\end{array}$ & $\begin{array}{l}\text { Total protein } \\
\text { ( } \mu \mathrm{g} / \mathrm{mg} \text { tissue })\end{array}$ & $\begin{array}{c}\text { NP-SH } \\
(\mathrm{nmol} / \mathrm{g})\end{array}$ \\
\hline Normal & $0.67 \pm 0.03$ & $126.94 \pm 4.10$ & $5.23 \pm 0.24$ \\
\hline $\mathrm{CCl}_{4}$ & $4.93 \pm 0.32^{* * *}$ & $48.30 \pm 3.35^{\star * \star}$ & $3.03 \pm 0.16^{* * *}$ \\
\hline Silymarin (10 mg/kg) & $1.27 \pm 0.07^{\star * *}$ & $108.18 \pm 4.16^{\star * *}$ & $5.06 \pm 0.40^{* * *}$ \\
\hline $\mathrm{ZS}-1(100 \mathrm{mg} / \mathrm{kg})$ & $3.13 \pm 0.11^{\star * *}$ & $67.46 \pm 2.42^{\star \star *}$ & $5.10 \pm 0.17^{* * *}$ \\
\hline ZS-1 (200 mg/kg) & $1.75 \pm 0.10^{\star \star \star}$ & $95.80 \pm 3.09^{\star \star \star}$ & $4.33 \pm 0.16^{* \star *}$ \\
\hline ZS-2 (100 mg/kg) & $5.08 \pm 0.30$ & $46.30 \pm 1.82$ & $3.44 \pm 0.27$ \\
\hline ZS-2 (200 mg/kg) & $4.13 \pm 0.14^{*}$ & $53.89 \pm 2.37$ & $3.24 \pm 0.18$ \\
\hline ZS-3 (100 mg/kg) & $4.92 \pm 0.23$ & $48.70 \pm 2.01$ & $3.14 \pm 0.13$ \\
\hline ZS-3 (200 mg/kg) & $3.55 \pm 0.05^{\star *}$ & $61.47 \pm 1.33^{* *}$ & $3.17 \pm 0.10$ \\
\hline ZS-4 (100 mg/kg) & $2.58 \pm 0.07^{\star * *}$ & $70.65 \pm 2.11^{* * *}$ & $4.21 \pm 0.27^{\star *}$ \\
\hline ZS-4 (200 mg/kg) & $1.74 \pm 0.09^{\star * *}$ & $95.00 \pm 2.87^{\star * \star}$ & $4.41 \pm 0.22^{* * *}$ \\
\hline
\end{tabular}

Each value represents mean \pm SEM $(n=3),{ }^{\star \star *} p<0.001 ;{ }^{* \star} p<0.01 ;{ }^{*} p<0.05 ; 1, \mathrm{CCl}_{4}$-only group compared to the normal control group; 2 , treated groups compared to the $\mathrm{CCl}_{4}$-only group 


\section{Inhibition of $\alpha$-glucosidase}

The inhibition of $\alpha$-glucosidase is shown in Figure 2. Among the 4 samples tested, the ZS-1 extract and ZS-2 fraction caused considerable inhibition compared to that by the ZS-4 and ZS-3 fractions in the order ZS-1 > ZS-2 > ZS-3 > ZS-4. ZS-1 exhibited the highest inhibition, whereas ZS-4 exhibited the lowest reduction at 100 $\mu \mathrm{g} / \mathrm{mL}$. The ZS-1 extract showed $54 \%$ inhibition at $100 \mu \mathrm{g} / \mathrm{ml}$ followed by ZS-2, $43 \%$; ZS-3, 37 $\%$; and ZS-4, $18 \%$.

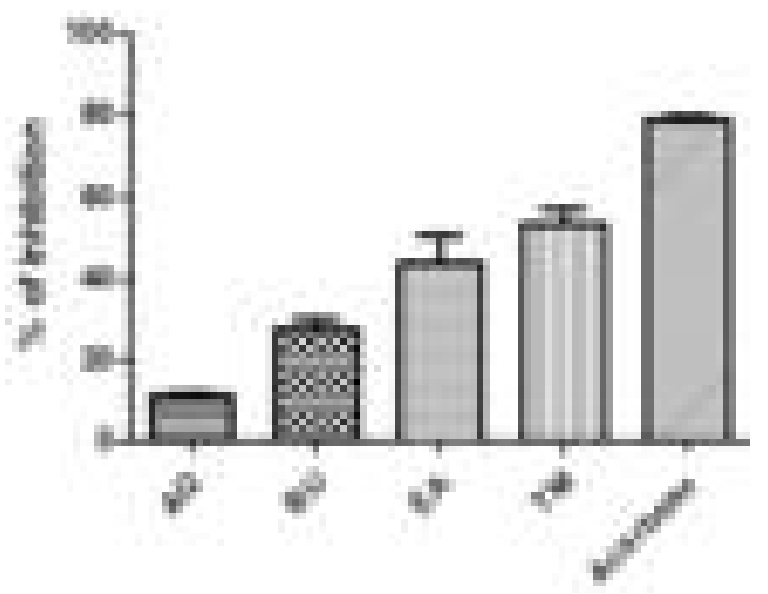

Figure 2: Inhibition of alpha-glucosidase activity. Key: ZS-4 (AQ); ZS-3(BU); ZS-2(EA); ZS-1(TM)

\section{Morphological features of liver}

In the control group, histopathological assessment of the liver sections revealed a normal histological architecture. The central vein was at the center of the lobules bounded by the hepatocytes containing strong eosinophilic granulated cytoplasm, and distinctive nuclei. In addition, hepatic sinusoids were observed within the strands of hepatocytes (Figure $3 \mathrm{~A}$ ). The livers of rats treated with $\mathrm{CCl}_{4}$ showed clear histopathological changes characterized by hepatocyte necrosis and hydropic degeneration (Figure $3 \mathrm{~B}$ ). Moreover, hepatocyte necrosis, inflammatory cell infiltration and congestion of the portal areas with noticeable hemorrhage were found in rats after $\mathrm{CCl}_{4}$ administration (Figure $3 \mathrm{~B}$ ).

In the silymarin $+\mathrm{CCl}_{4}$ group, liver sections appeared more or less normal (Figure 3C) and microscopic examination of liver from the ZS-1 (100 or $200 \mathrm{mg} / \mathrm{kg})+\mathrm{CCl}_{4}$ group revealed improvements in the liver structure, except minor hepatocyte necrosis (Figure 3 D and $E$, respectively).
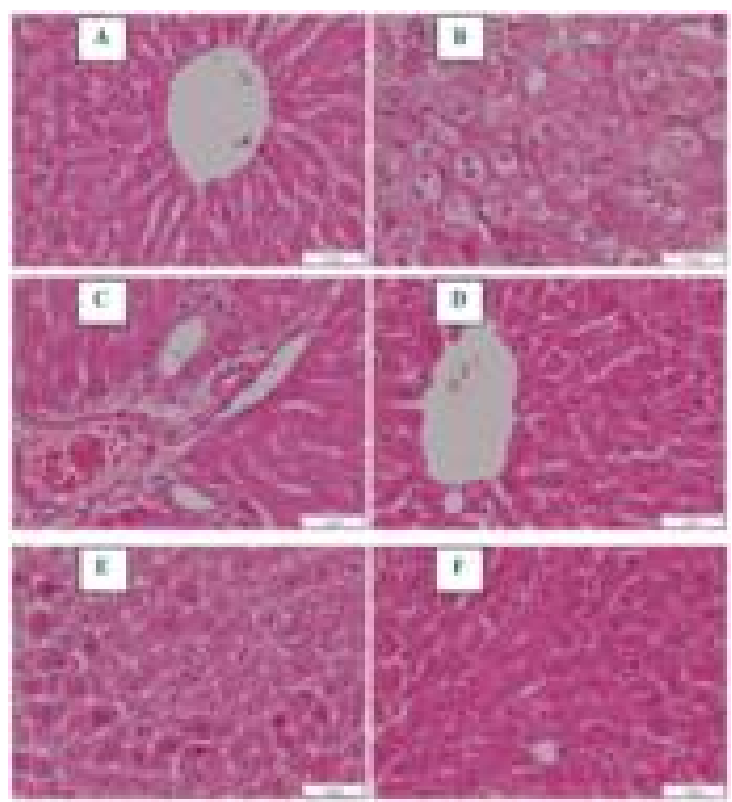

Figure 3: Sections of the liver tissue from the: (A) Normal control, (B) $\mathrm{CCl}_{4}$-only treatment group, (C) Silymarin $+\mathrm{CCl}_{4}$ treatment group, (E) ZS-1 (100 $\mathrm{mg} / \mathrm{kg})+\mathrm{CCl}_{4}$ treatment group, (F) ZS-1 (200 mg/kg) $+\mathrm{CCl}_{4}$ treatment group

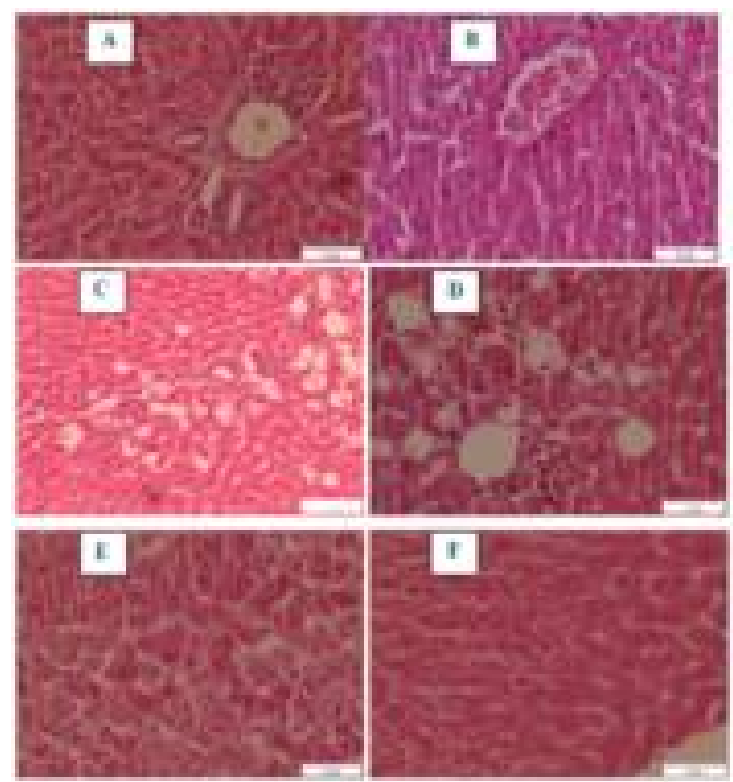

Figure 4: Sections of the liver tissue from the: (A) ZS$2(100 \mathrm{mg} / \mathrm{kg})+\mathrm{CCl}_{4}$ treatment group, (B) ZS-2 (200 $\mathrm{mg} / \mathrm{kg})+\mathrm{CCl}_{4}$ treatment group, (C) ZS-3 (100 mg/kg) $+\mathrm{CCl}_{4}$ treatment group, (D) ZS-3 $(200 \mathrm{mg} / \mathrm{kg})+\mathrm{CCl}_{4}$ treatment group; (E) ZS-4 (100 mg/kg) $+\mathrm{CCl}_{4}$ treatment group; (F) ZS-4(200 mg/kg) $+\mathrm{CCl}_{4}$ treatment group

Sections of the liver from the ZS-2 $(100 \mathrm{mg} / \mathrm{kg})+$ $\mathrm{CCl}_{4}$ group displayed congested portal areas with moderate inflammatory cell infiltration (Figure 4 A) while from the $\mathrm{ZS}-2(200 \mathrm{mg} / \mathrm{kg})+\mathrm{CCl}_{4}$ group, a disturbance in the hepatic lobule structure was associated with the congested central veins 
(Figure $4 \mathrm{~B}$ ). In the ZS-3 (100 or $200 \mathrm{mg} / \mathrm{kg})+$ $\mathrm{CCl}_{4}$ group, changes in the level of fat and inflammatory cell infiltration were observed (Figure $4 \mathrm{C}$ and $4 \mathrm{D})$. In the ZS-4 $(100 \mathrm{mg} / \mathrm{kg})+$ $\mathrm{CCl}_{4}$ group, focal necrosis of hepatocytes was found (Figure $4 \mathrm{E})$, while in the ZS-4 $(200 \mathrm{mg} / \mathrm{kg})$ $+\mathrm{CCl}_{4}$ group, the structure of liver appeared more or less similar to that of the control (Figure $4 \mathrm{~F})$.

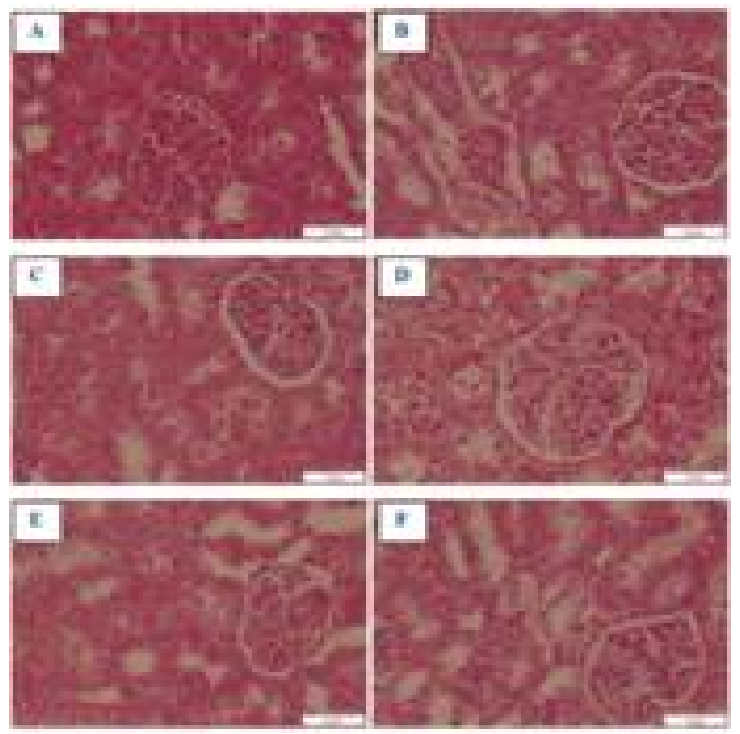

Figure 5: Sections of the kidney from: (A) Normal control, (B) $\mathrm{CCl}_{4}$-only treatment group, (C) Silymarin + $\mathrm{CCl}_{4}$ treatment group, (D) ZS-1, $100 \mathrm{mg} / \mathrm{kg}+\mathrm{CCl}_{4}$ treatment group, (E) ZS-1 (200 mg/kg) $+\mathrm{CCl}_{4}$ treatment group, (F) ZS-2 (100 mg/kg) $+\mathrm{CCl}_{4}$ treatment group
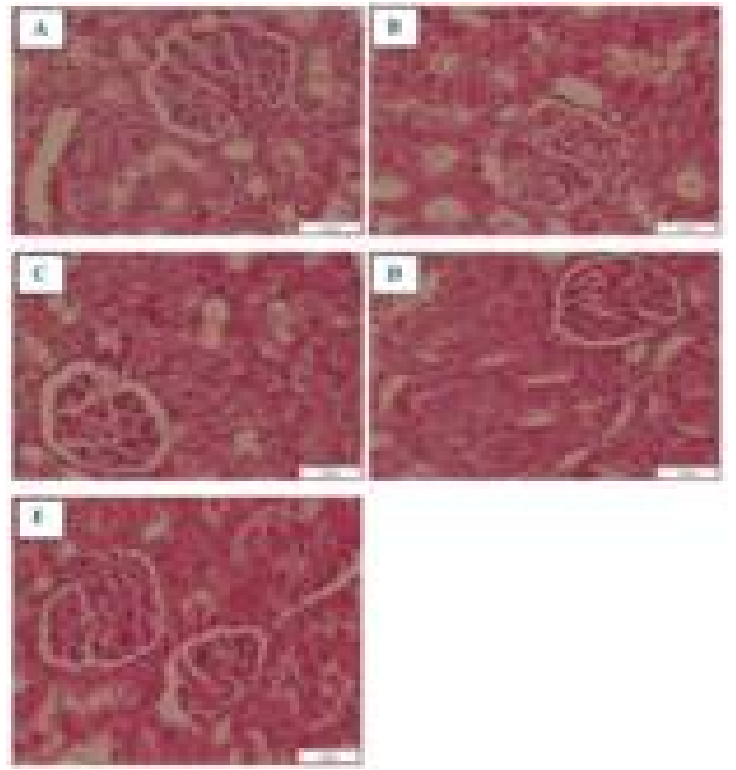

Figure 6: Sections of the kidney treated with: (A) ZS-2 $(200 \mathrm{mg} / \mathrm{kg})+\mathrm{CCl}_{4},(\mathrm{~B}) \mathrm{ZS}-3(100 \mathrm{mg} / \mathrm{kg})+\mathrm{CCl}_{4},(\mathrm{C})$ ZS-3 $(200 \mathrm{mg} / \mathrm{kg})+\mathrm{CCl}_{4}$, (D) ZS-4 $(100 \mathrm{mg} / \mathrm{kg})+\mathrm{CCl}_{4}$, (E) ZS-4 $(200 \mathrm{mg} / \mathrm{kg})+\mathrm{CCl}_{4}$

\section{Morphological features of Kidney}

Histopathological examination of kidney sections from the control group showed renal tubules, renal corpuscles, distal convoluted tubules and proximal convoluted tubules. Furthermore, the glomerulus, urinary space and Bowman's capsule appeared as shown in Figure $5 \mathrm{~A}$. Sections of the kidney from the $\mathrm{CCl}_{4}$ group showed glomerular and tubular degeneration, interstitial hemorrhage, infiltration, and tubular widening of the lumen (Figure $5 \mathrm{~B}$ ). Sections from the Silymarin $+\mathrm{CCl}_{4}$ group showed glomerular and tubular structure similar to that of the control (Figure $5 \mathrm{C}$ ). Examination of kidney from the ZS-1 $(100 \mathrm{mg} / \mathrm{kg})+\mathrm{CCl}_{4}$ group showed tubular degeneration (Figure $5 \mathrm{D}$ ) while kidneys from the ZS-1 $(200 \mathrm{mg} / \mathrm{kg})+\mathrm{CCl}_{4}$ group appeared more or less similar to the control (Figure 5E). Microscopic examination showed glomerular and tubular degeneration in the kidneys from the ZS-2 $(100 \mathrm{mg} / \mathrm{kg})+\mathrm{CCl}_{4}$, ZS-2 $(200 \mathrm{mg} / \mathrm{kg})+\mathrm{CCl}_{4}, Z \mathrm{ZS}-3(100 \mathrm{mg} / \mathrm{kg})+\mathrm{CCl}_{4}$, ZS-3 $(200 \mathrm{mg} / \mathrm{kg})+\mathrm{CCl}_{4}, \mathrm{ZS}-4(100 \mathrm{mg} / \mathrm{kg})+$ $\mathrm{CCl}_{4}$ groups, (Figure $5 \mathrm{~F}$, Figure $6 \mathrm{~A}-\mathrm{D}$, respectively). Moreover, histopathological investigation of the ZS-4 $(200 \mathrm{mg} / \mathrm{kg})+\mathrm{CCl}_{4}$ group showed that the glomerular and tubular structure appeared more or less similar to the normal (Figure $6 \mathrm{E}$ )

\section{DISCUSSION}

As severe liver damage can be initiated by administering $\mathrm{CCl}_{4}$, a hepatotoxin, to rats, this has contributed to its use in the study of liver disorders. The hepatotoxicity effect of $\mathrm{CCl}_{4}$ is caused by the trichloromethyl free radical. This highly active free radical causes cell death or damage, which completely disturbs the body's lipid profile [14]. Liver enzymes (SGOT, SGPT and ALP) are considered to be the most widespread biochemical markers to assess liver injury as they are present in the cytoplasm of cells and are released into circulation during cellular injury [18]. The activities of such enzymes in serum can therefore reveal the severity of liver alterations [19]. The abundance of these biomarkers compared to that in normal conditions indicates dysfunction of the liver. These impairment can be studied histopathologically with the help of necrotic hepatocytes that appear in liver tissues [20].

By administering $\mathrm{CCl}_{4}$ in the current study, we reveal a significant enhancement in ALP, SGOT and SGPT levels, indicating that $\mathrm{CCl}_{4}$ intoxication disrupts the integrity of the hepatic cell membranes [21]. Pretreatment with methanol and aqueous Zizyphus spina-christi L. extract 
significantly decreased the levels of SGOT, SGPT and ALP toward normal levels. These observations align with the notion that serum concentrations of transaminases revert due to the effect of $\mathrm{CCl}_{4}$ in repairing hepatic tissue damages and plasma membrane stabilization [22].

The histopathological study revealed extensive architecture distortion, congestion, necrosis and inflammation, which were successfully stimulated by $\mathrm{CCl}_{4}$ administration. In the adopted mechanism of $\mathrm{CCl}_{4}$ hepatotoxicity via reductive dehalogenation catalyzed by $\mathrm{P}_{450}$, the extremely reactive trichloromethyl $\left(\mathrm{CCl}_{3}\right)$ free radical readily interacts with molecular oxygen to form the trichlomethyl peroxyl radical $\left(\mathrm{CCl}_{3} \mathrm{OO}\right)$ [19]. This radical can then bind to lipids, causing lipid peroxidation and consequently liver destruction to greatly contribute to the pathogenesis of diseases [23].

The histological appearance in the total methanol (ZS-1) and aqueous (ZS-4) Zizyphus spinachristi L. groups was partly similar to that of the control group, and tissue injuries and necrosis occurred at a lesser extent in these groups than in the $\mathrm{CCl}_{4}$ group. The overall histopathological findings correlate with the biochemical parameters and suggest that total methanol (ZS1) and aqueous (ZS-4) Zizyphus spina-christi $L$. may be effective against $\mathrm{CCl}_{4}$-induced changes in the liver. The reduction in total protein level could be viewed as a helpful indicator of the degree of hepatocellular injury [24].

In this investigation, $\mathrm{CCl}_{4}$ intoxication decreased total protein level in the tissue. This was due to the formation and restriction of the preliminary injury to the endoplasmic reticulum, damaging cytochrome P-450 enzymes and reducing their function in the synthesis of protein and triglycerides which causes fatty liver [25]. Preceding studies have shown that administering $\mathrm{CCl}_{4}$ to different animals results in a rapid reduction in protein synthesis in the liver [14]. Pretreatment with the extract and fractions of $Z S$ 1 and ZS-4 Zizyphus spina-christi L., and $\mathrm{CCl}_{4}$ restored total protein level, stabilizing the endoplasmic reticulum for protein synthesis [24]

Due to its antioxidant ability, bilirubin is considered a cytoprotectant [21]. At this time, administering $\mathrm{CCl}_{4}$ raises the possibility of renal malfunction by increasing serum creatinine and total bilirubin [14]. Reduction in bilirubin and serum creatinine concentrations in the groups treated with the different fractions of plant extract enhanced the contributory mechanism of lowered oxidative stress. The kidney assists in the maintenance of homeostasis in the body by reabsorbing vital materials and eliminating waste.

Creatinine is commonly used as a measure of kidney function and its increased level in the blood is considered an indicator of kidney damage. In the current investigation, treatment with $\mathrm{CCl}_{4}$ significantly increased creatinine level. The observed increase is an investigative indicator of cellular leakage and cell membrane damage in renal tissues [26]. The current study showed that $\mathrm{CCl}_{4}$ induces renal injury due to the high uric acid and serum creatinine levels, elevated MDA concentration and the reduced contents of protein and NP-SH in the kidney of treated animals, all of which closely agree with previous studies. Elevated levels of uric acid and creatinine are indices of nephrotoxicity [26]. Uric acid and serum creatinine are the final compounds of purine and can modify the glomerular filtration rate. Alterations of the glomerular filtration rate increase serum creatinine and uric acid levels which are associated with renal damage [27].

Co-administering ZS-1 and ZS-4 in the current study successfully prevented harm related to $\mathrm{CCl}_{4}$ administration in the renal system, as depicted by the renal functioning biomarkers and histopathological test. Methanol and aqueous Zizyphus spina-christi $L$ significantly decreased serum creatinine and uric acid In addition, the extract evidently enhanced NP-SH and protein depletion in kidney tissue, and significantly reduced MDA concentration, which were increased by $\mathrm{CCl}_{4}$ treatment.

\section{CONCLUSION}

Co-administering ZS-1 and ZS-4 of Zizyphus spina-christi $L$. results in hepatoprotective effects against liver injury induced by $\mathrm{CCl}_{4}$. Therefore, we recommend this plant for further bioactive phytochemical screening in vivo evaluation.

\section{DECLARATIONS}

\section{Acknowledgement}

This study was supported by the Deanship of Scientific Research (DSR), King Abdulaziz University, Jeddah (grant no. G-117-247-1439). The authors gratefully acknowledge this support.

\section{Conflict of interest}

No conflict of interest is associated with this work. 


\section{Contribution of authors}

We declare that this work was done by the authors named in this article and all liabilities pertaining to claims relating to the content of this article will be borne by the authors. AAM Al-Gh, and AAS carried out the study; MEI-Z, and AAS designed the experiments. AAM-Al-Gh and AAS wrote the manuscript; MEI-Z, and AAS supervised the work; all authors read and approved the final manuscript.

\section{Open Access}

This is an Open Access article that uses a funding model which does not charge readers or their institutions for access and distributed under the terms of the Creative Commons Attribution License (http://creativecommons.org/licenses/by/ 4.0) and the Budapest Open Access Initiative (http://www.budapestopenaccessinitiative.org/rea d), which permit unrestricted use, distribution, and reproduction in any medium, provided the original work is properly credited.

\section{REFERENCES}

1. Kohn S, Fradis M, Robinson E, lancu TC. Hepatotoxicity of combined treatment with cisplatin and gentamicin in the guinea pig. Ultrastruct Pathol 2005; 29(2): 129-137.

2. Ahsan MR, Islam KM, Bulbul IJ, Musaddik MA, Haque E. Hepatoprotective activity of methanol extract of some medicinal plants against carbon tetrachloride-induced hepatotoxicity in rats. Eur J Sci Res 2009; 37(2): 302310.

3. Siripong $P$, Kongkathip $B$, Preechanukool K, Picha $P$, Tunsuwan $K$, Taylor $W$. Cytotoxic diterpenoid constituents from Andrographis paniculata Nees leaves. J Sci Soc Thai 1992; 18(4): 187-194.

4. Oluma H, Umeh E, Onekutu A, Okolo J. Antibacterial potentials of eight medicinal plants from the lower Benue valley of Nigeria. Niger J Bot 2004; 17: 1-11.

5. Kazeem M, Adamson J, Ogunwande I. Modes of inhibition of $\alpha$-amylase and $\alpha$-glucosidase by aqueous extract of Morinda lucida Benth leaf. BioMed Res Int 2013; 2013: 1-9.

6. Youssef H, Khedr A, Mahran M. Hepatoprotective activity and antioxidant effects of Napk (Zizyphus spina-christi L.) fruits on rats hepatoxicity induced by carbon tetrachloride. Nutr Sci 2011; 2011: 1-7.

7. Abalaka M, Daniyan S, Mann A. Evaluation of the antimicrobial activities of two Ziziphus species (Ziziphus mauritiana L. and Ziziphus spinachristi L.) on some microbial pathogens. Afr J Pharm Pharmacol 2010; 4(4):135-139.

8. Kritiker K. Indian medicinal plants, Lalit Mohan Basu. Allahabad, India 1984, 1:788-789.
9. Adzu B, Haruna AK. Studies on the use of Zizyphus spina-christi against pain in rats and mice. Afr $J$ Biotechol 2007; 6(11): 1317-1324.

10. Kaaria I. Seed production, dispersal and germination in Cryptostegia grandifolia and Ziziphus mauritiana, two invasive shrubs in tropical woodlands of Northern Australia. Aust J Ecol 1998; 21(3): 324-331.

11. Michel A. Tree, shrub and liana of West African zone. In.: Margraf Publishers GMBH, Paris; 2002.

12. Al-Ghamdi $A A$, Shahat AA. Antioxidant, hypoglycemic and anti-diabetic activities of Ziziphus spina-christi ( $L$ ) Willd (Rhamnacae) leaf extract. Trop J Pharm Res 2017; 16(11): 2601-2610.

13. Asgarpanah J, Haghighat E. Phytochemistry and pharmacologic properties of Zizyphus spina-christi $L$. willd. Afr J Pharm Pharmacol 2012; 6: 2332-2339.

14. Ullah R, Alsaid MS, Shahat AA, Naser AA, Al-Mishari AA, Adnan M, Tariq A. Antioxidant and Hepatoprotective Effects of Methanolic Extracts of Zilla spinosa and Hammada elegans Against Carbon Tetrachlorideinduced Hepatotoxicity in Rats. Open Chem 2018; 16(1): 133-140.

15. Shahat AA, Ullah R, Alqahtani AS, Alsaid MS, Husseiny $H A, \quad A l$ Meanazel OT. Hepatoprotective Effect of Eriobotrya japonica Leaf Extract and Its Various Fractions against Carbon Tetra Chloride Induced Hepatotoxicity in Rats. Evid Based Complement Alternat Med 2018; 2018: 1-8

16. Sabitha $V$, Panneerselvam $K$, Ramachandran S. In vitro $\alpha$-glucosidase and $\alpha$-amylase enzyme inhibitory effects in aqueous extracts of Abelmoscus esculentus (L.) Moench. Asian Pac J Trop Biomed 2012; 2(1): S162S164.

17. Hossain SJ, Tsujiyama I, Takasugi M, Islam MA, Biswas RS, Aoshima H. Total phenolic content, antioxidative, anti-amylase, anti-glucosidase, and antihistamine release activities of Bangladeshi fruits. Food Sci Technol Res 2008; 14(3): 261-268.

18. Naik SR, Panda VS. Hepatoprotective effect of Ginkgoselect Phytosome $\AA$ in rifampicin induced liver injury in rats: Evidence of antioxidant activity. Fitoterapia 2008; 79(6): 439-445.

19. Ranawat L, Bhatt J, Patel J. Hepatoprotective activity of ethanolic extracts of bark of Zanthoxylum armatum DC in $\mathrm{CCl} 4$ induced hepatic damage in rats. $J$ Ethnopharmacol 2010; 127(3): 777-780.

20. Al-Mehdar AA, El-Denshary ES, Addel-wahhab M. Alpha Lipoic Acid and Alpha-Tocopherol counteract the Oxidative Stress and Liver Damage in Rats SubChronically Treated with Khat (Catha edulis) Extract. Global J Pharmacol 2012; 6: 94-105.

21. Aniya $Y$, Koyama $T$, Miyagi $C$, Miyahira $M$, Inomata $C$, Kinoshita S, Ichiba $T$. Free radical scavenging and hepatoprotective actions of the medicinal herb, Crassocephalum crepidioides from the Okinawa Islands. Biol Pharm Bull 2005; 28(1): 19-23. 
22. Halliwell B, Gutteridge JM. Role of free radicals and catalytic metal ions in human disease: an overview. Methods Enzymol 1990; 186: 1-85.

23. Soni B, Visavadiya NP, Madamwar D. Ameliorative action of cyanobacterial phycoerythrin on $\mathrm{CCl}_{4}$-induced toxicity in rats. Toxicology 2008; 248(1): 59-65.

24. Gowda S, Desai PB, Kulkarni SS, Hull VV, Math $A A$, Vernekar SN. Markers of renal function tests. North Am J Med Sci 2010; 2(4): 170-173.
25. Najafi M. Serum creatinine role in predicting outcome after cardiac surgery beyond acute kidney injury. World J Cardiol 2014; 6(9): 1006-1021.

26. Mika D, Guruvayoorappan C. The effect of Thespesia populnea on cisplatin induced nephrotoxicity. J Can Res Ther 2013; 9(1): 50-53

27. Ullah N, Khan M, Khan T, Ahmad W. Cymbopogon citratus protects against the renal injury induced by toxic doses of aminoglycosides in rabbits. Indian J Pharm Sci 2013; 75(2): 241-146. 